\title{
Cryptic species in a Vulnerable seabird: short-tailed albatross consists of two species
}

\author{
Masaki Eda ${ }^{1, *}$, Takeshi Yamasaki ${ }^{2}$, Hiroe Izumi ${ }^{1}$, Naoki Tomita $^{3}$, Satoshi Konno ${ }^{3}$, \\ Miwa Konno ${ }^{3}$, Hayao Murakami ${ }^{3}$, Fumio Sato $^{3}$
}

\author{
${ }^{1}$ Hokkaido University Museum, Hokkaido University, Kita 10, Nishi 8, Kita-ku, Sapporo 060-0810, Japan \\ ${ }^{2}$ Division of Natural History, Yamashina Institute for Ornithology, Konoyama 115, Abiko 270-1145, Japan \\ ${ }^{3}$ Division of Avian Conservation, Yamashina Institute for Ornithology, Konoyama 115, Abiko 270-1145, Japan
}

\begin{abstract}
The occurrence of cryptic species within a threatened taxon is rare, but where they do occur, understanding species boundaries is essential for planning an effective conservation strategy. The short-tailed albatross Phoebastria albatrus is a Vulnerable seabird that mainly breeds on Torishima and the Senkaku Islands in the western North Pacific. Although it has been tacitly regarded as a single management unit with 2 breeding sites, the species is known to comprise 2 genetically separated populations (Senkaku-type and Torishima-type). However, morphological examination of birds from both populations has not been conducted owing to the difficulty in accessing the Senkaku Islands. In this study, we examined the morphological differences between immigrants from the Senkaku Islands to Torishima (Senkaku-type) and native birds on Torishima (Torishima-type) and found significant differences in morphological characteristics between the 2 bird types. In general, Torishima-type birds were larger than Senkaku-type birds, whereas Senkaku-type birds had relatively longer beaks. Based on the morphological differences found in this study as well as genetic and ecological differences revealed in previous studies, we believe that Senkaku- and Torishima-type birds should be classified as different cryptic species. To the best of our knowledge, this is the first case of cryptic species being identified in a threatened avian species.
\end{abstract}

KEY WORDS: Birds · Conservation $\cdot$ Cryptic species $\cdot$ Short-tailed albatross $\cdot$ Threatened species

\section{INTRODUCTION}

The term 'cryptic species' refers to 2 or more species that are classified, or have been classified, as a single nominal species because of their (at least superficially) indistinguishable morphology (Bickford et al. 2007). Although this concept has been recognised for nearly $300 \mathrm{yr}$ (Winker 2005), it is only over the last 2 decades that molecular delimitation methods have revealed that cryptic species are quite common and widespread across most animal phyla (Pfenninger \& Schwenk 2007, Adams et al. 2014, Pérez-Ponce de León \& Poulin 2016). Cryptic species

\footnotetext{
${ }^{*}$ Corresponding author: edamsk@museum.hokudai.ac.jp
}

require special consideration in conservation planning because a species already considered threatened may be composed of multiple species that are even more rare than previously thought (Bowen et al. 1991, Schönrogge et al. 2002, Ravaoarimanana et al. 2004, Sugawara et al. 2018, Yan et al. 2018). The discovery of cryptic species within a threatened species is rare, but has been found in the myrmecophilous hoverfly Microdon mutabilis (Schönrogge et al. 2002), lentic salamander Hynobius dunni (Sugawara et al. 2018), Chinese giant salamander Andrias davidianus (Yan et al. 2018), olive ridley sea turtle Lepidochelys olivacea (Bowen et al. 1991), and Malagasy

() The authors 2020. Open Access under Creative Commons by Attribution Licence. Use, distribution and reproduction are unrestricted. Authors and original publication must be credited. 
lemur Lepilemur septentrionalis (Ravaoarimanana et al. 2004). These discoveries are essential for planning appropriate conservation strategies because each different species might have different requirements for effective conservation (Schönrogge et al. 2002, Davidson-Watts et al. 2006).

The short-tailed albatross Phoebastria albatrus is a Vulnerable (D2) (BirdLife International 2018) seabird found in the north Pacific Ocean. Although several million birds bred in at least 14 colonies in the late $19^{\text {th }}$ century, the number of individuals was drastically reduced owing to feather hunting during the late $19^{\text {th }}$ and early $20^{\text {th }}$ centuries (Tickell 2000, Hasegawa 2003, US Fish and Wildlife Service 2008), and they were once declared extinct in 1949 (Austin 1949). In 1951, however, a remnant population was re-discovered at the Tsubamezaki colony on Torishima Island. During the 1954-1955 breeding season, only 23 birds and 7 eggs were observed worldwide, all on Torishima (Ono 1955, Fujisawa 1967). Thereafter, the number of birds began to increase as a result of conservation efforts, and adult birds were also found on Minamikojima Island, Senkaku Islands in 1971 (Research Group for Senkaku Islands at Ryukyu University 1971). Furthermore, artificial translocation of chicks from Torishima to Mukojima Island in the Bonin Islands during the 2008 and 2012 breeding seasons resulted in the establishment of a new colony in the Bonin Islands (Deguchi et al. 2017). At the end of the 2013-2014 breeding season, the global population was estimated to be 4200 individuals, with 3540,650, and 10 birds on Torishima, the Senkaku Islands, and the Bonin Islands, respectively (Deguchi et al. 2017, BirdLife International 2018). Research on the Senakaku Islands has not been conducted since 2002, mainly because of the difficulty in accessing the islands due to political reasons.

The short-tailed albatross was tacitly regarded as a single management unit with 2 breeding sites, and international conservation projects considered its population structure to be of low concern (US Fish and Wildlife Service 2008, Deguchi et al. 2012, BirdLife International 2017), although previous studies suggest that the species could include cryptic species (Eda 2004, Eda \& Higuchi 2012, Eda et al. 2012, 2016). Eda (2004) and Eda et al. (2012) found that the 2 populations of short-tailed albatross existed $\sim 1000$ yr ago, and descendants of each population seem to have survived, basically on Torishima and the Senkaku Islands. Additionally, they revealed that the sequence divergence between the 2 clades is greater than that between other Diomedeidae sister species (Eda \& Higuchi 2012), and that strong but incomplete pre-mating isolation was observed between birds fledged on Torishima and those fledged on Senkaku Islands when they bred sympatrically (Eda et al. 2016). Thus, in addition to these lines of genetic and behavioural evidence, morphological examination of individuals of the 2 types is essential for taxonomic re-evaluation of the species (Eda \& Higuchi 2012, Eda et al. 2016). However, the difficulty in accessing the Senkaku Islands has prevented examination.

Recently, bird censuses and genetic analyses revealed that immigrants from the Senkaku Islands have been breeding on Torishima (Eda et al. 2011, 2016). Since 1979, attempts have been made to attach at least one leg ring to all albatrosses hatched on Torishima before they leave the island (Sato 1999, Yamashina Institute for Ornithology 2005). In total, 4146 short-tailed albatrosses were ringed from April 1992 to March 2014 (Yamashina Institute for Ornithology 2002-2015), and 4140 nestlings were counted over 23 breeding seasons (from 1991-1992 to 20132014) on Torishima (Hasegawa 2015). However, unringed subadult plumage birds have been observed every year since 1996 in the Hatsunezaki colony, which is located in the northwest of Torishima and was artificially established using decoys and audio devices (Sato 2009). Moreover, the number of unringed birds has increased. As it is unlikely that these unringed subadult plumage birds hatched on Torishima before 1979 or that they lost their ring(s), their natal site is suspected to be the Senkaku Islands rather than Torishima. This conjecture was supported by genetic analysis, because all of the 10 unringed birds captured shared haplotypes from a genetic lineage that was observed in all birds from the Senkaku Islands captured before 2002 but this applied to only $7.3 \%$ of the birds that hatched on Torishima (Kuro-o et al. 2010, Eda et al. 2011, 2016).

In this study, we examined morphological differences between birds from the Senkaku Islands and Torishima for taxonomic re-evaluation of the species and to fill the gap of morphological surveys. For this purpose, ringed and unringed birds were captured and measured on Torishima, and their mitochondrial DNA (mtDNA) control region (CR) 2 was analysed to confirm the origin population (= type) for each bird. Results revealed morphological differences between the 2 short-tailed albatross populations. The existence of cryptic species for this Vulnerable seabird is also discussed. 


\section{MATERIALS AND METHODS}

\subsection{Field studies}

We captured adult short-tailed albatrosses in the Hatsunezaki colony on Torishima (Fig. 1) during the 2012-2013 and 2018-2019 breeding seasons. To reduce the disturbance to breeding behaviour of birds in the colony, we carefully selected isolated individuals as capture targets. Short-tailed albatrosses were captured with permission from the Ministry of the Environment and the Agency for Cultural Affairs, Government of Japan, and in compliance with their guidelines. Most birds in the colony were ringed and confirmed to have fledged from Torishima, while some were unringed and suspected to have emigrated from the Senkaku Islands (Eda et al. 2011). Genetic analysis of 9 of the 14 unringed birds was

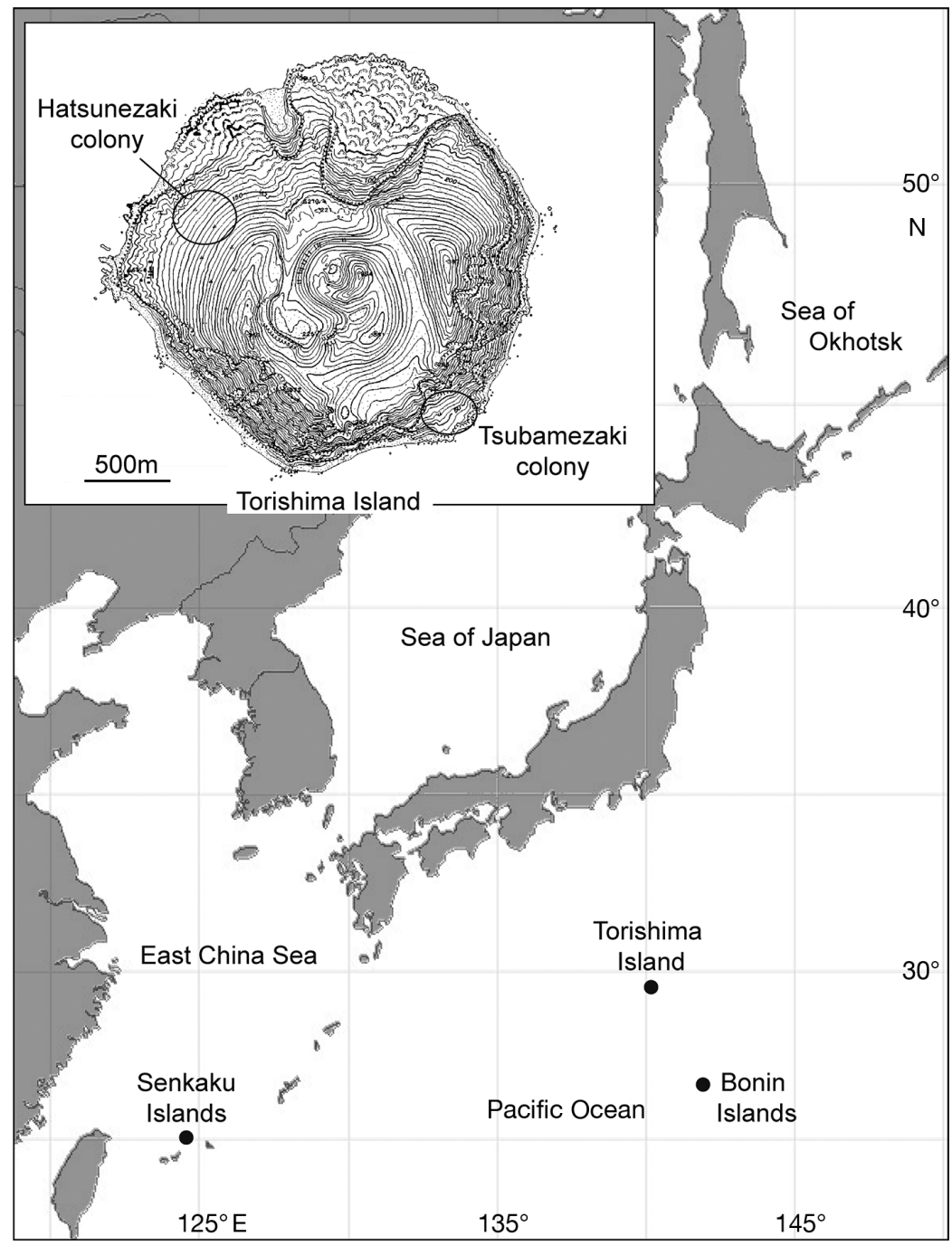

Fig. 1. Short-tailed albatross breeding sites performed in a previous study (Eda et al. 2016), which confirmed that they shared the mtDNA CR2 haplotypes mainly observed in birds from the Senkaku Islands.

We took a maximum of 26 morphological measurements for each bird: total length (TL), half wing span (WS), natural wing (NW), tail length (TAIL), tarsus length (TAR), total head length (TH), beak to gape length (Gape), skull width (SK-W), exposed culmen (EC), beak height at base $(\mathrm{BH})$, beak width at base (BW), beak tip to nostrils front length (NF), beak height at nostrils (NFH), beak width at nostrils (NFW), premaxillary nail length (PNL), mandibular nail length (MNL), eye diameter (EYE), wing base to tip length (WB-T), primary base width (PBW), scapular base width (SBW), tarsus thickness (TT), tarsus width (TW), web width (WW), web length (WL), ankle to web length $(\mathrm{A}-\mathrm{W})$, and body weight (Table S1, Fig. S1 in the Supplement at www.intres.com/articles/suppl/n043p375_supp. pdf), but some morphological variables were only measured in individuals captured at a later point in the study.

To conduct a molecular phylogenetic analysis and molecular sexing, blood samples ( 0.5 ml) were taken from the cutaneous ulnar vein of the birds. Blood obtained was preserved in $99.5 \%$ ethanol and stored, first in a cool dark place (in the field) and then in refrigerated conditions (in the laboratory), until analyses.

\subsection{DNA analysis}

To reveal the phylogenetic position of each bird, the mtDNA CR2 domain I (341 bp) sequence was determined for all birds as described in Eda et al. (2016). We refer to CR'2' owing to the duplication of CR in Diomedeidae including Phoebastria albatrosses (Abbott et al. 2005, Eda et al. 2010). In brief, whole DNA was extracted from blood samples using a Puregene DNA isolation kit (QIAGEN), CR2 domain I was amplified via polymerase chain reaction (PCR) using primers Lcon2.dio (Eda et al. 2010) and H454.gr (Baba et al. 2005), and PCR products were cycle-sequenced using an ABI BigDye Terminator ver. 1.1 Cycle Sequencing 
kit (Thermo Fisher Scientific) and run on an ABI PRISM 3130 genetic analyser (Thermo Fisher Scientific). The obtained sequences were aligned with 24 sequences from 53 P. albatrus individuals sampled on Torishima (41 ringed chicks, 9 unringed adults) and the Senkaku Islands (1 chick, 2 adults) (GenBank accession numbers AB254197-AB254240 and LC066675-LC066677) using ClustalX in MEGA 7.0 (Kumar et al. 2016). Four sequences of Laysan albatross P. immutabilis (AB276048-AB276050 and AB276055) and 5 sequences of black-footed albatross P. nigripes (AB276051, AB276057, AB276059, AB27 6061, and AB276063) were included as outgroup sequences. A neighbour-joining (NJ) tree with 1000 bootstrap replications was constructed for the obtained sequences from each bird and 33 sequences retrieved from GenBank with MEGA 7.0. To identify the sex of each bird, we used the CHD gene following established protocols (Fridolfsson \& Ellegren 1999).

\subsection{Morphological analysis}

Morphological differences between sexes and populations were tested using $t$-tests, a principal component analysis (PCA), and discriminant function analysis (DFA). Because the molecular analyses revealed that captured birds were biased to male and that female birds originating from Torishima were rare (see Section 3.2), morphological sexual differences were tested only for birds originating from the Senkaku Islands, while morphological population differences were tested only for male birds. To reveal the general morphological similarities and dissimilarities between populations and sexes, a PCA was conducted using the 9 measurements obtained for all captured individuals (WS, TAIL, TAR, TH, Gape, EC, $\mathrm{NF}, \mathrm{NFH}$, and NFW), using a correlation matrix. To reveal the effective discriminant criteria between males from the 2 populations, DFA was conducted using 3 beak measurements (EC, BH, and NFH) after a homogeneity test of covariance matrices. The reason for this selection was higher applicability for old skin (all measurements), less overlap between the populations (BH and NFH), and proportional difference between the 2 populations (EC) (see Section 3.3). DFA was performed using the linear and quadratic discriminant function, as covariance matrices were not significantly different among species (see Section 3.3). Leave-one-out classification was performed to test the robustness of the identification criteria. All statistical analyses were conducted using Systat 13
(Systat Software). All measurements were log transformed before conducting the analyses.

\section{RESULTS}

\subsection{Field studies}

During the research seasons, we captured 24 (10 ringed, 14 unringed) adult short-tailed albatrosses. Although blood was collected from all captured birds, measurements were not completed for some birds because of the bird's condition and some measurements were only taken at a later point in the study (Table 1).

\subsection{DNA analysis}

The target mtDNA CR2 sequence was determined for all bird blood samples, and 12 haplotypes were found. By comparing these haplotypes with those available in the GenBank database, we identified 4 as newly observed; these were deposited in the database with accession numbers LC534780-LC534782. The NJ tree clearly showed that there were 2 major clades in the short-tailed albatross, which were supported by 80 and $95 \%$ bootstrap values, respectively (Fig. 2). All 10 sequences from the ringed birds clustered with 18 of 20 sequences from Tsubamezaki colony on Torishima. Thus, birds belonging to the clade are referred to herein as Torishima-type. All sequences obtained from 5 individuals without rings clustered with 3 sequences from the Senkaku Islands and previously analysed 9 unringed birds, and with 2 sequences from the Tsubamezaki colony. Thus, birds belonging to this clade are referred to herein as the Senkaku-type. Molecular sexing revealed that 10 out of 14 Senkaku-type birds and 8 out of 10 Torishimatype birds were male, and the remainder were female.

\subsection{Morphological analysis}

After identification and sexing, it was apparent that 26, 13, 26, and 24 measurements were recorded for Senkaku-type males, Senkaku-type females, Torishima-type males, and Torishima-type females, respectively (Table 1). For Senkaku-type birds, males were larger than females on average for 12 out of 13 variables, with TAIL being the exception. Significant sexual morphological differences were revealed in 3 


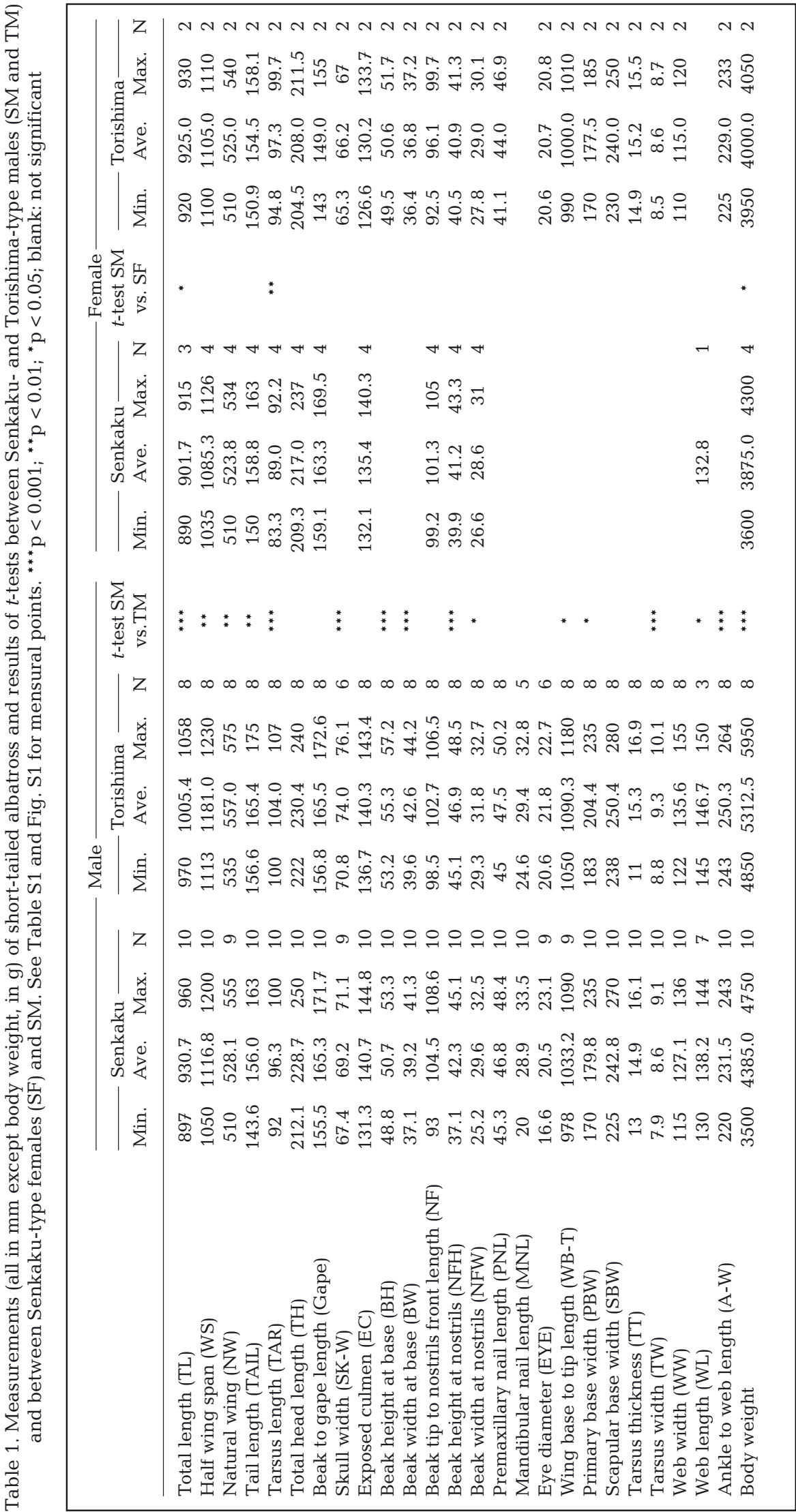

out of 13 measurements (TL, TAR, and body weight) for Senkakutype birds, while measurements for males and females overlapped for all measured variables. As there were only 2 female Torishima-type birds, their morphological sexual difference could not be statistically tested. However, on average, female birds were smaller than male birds for all 24 measurements. In addition, both female birds were smaller than the smallest male bird for 15 of the 24 measurements. On average, Torishima-type males were larger than Senkaku-type males for 24 of 26 mensural points, with EC and NF being the exceptions. Moreover, TL and body weight values of the smallest Torishimatype male bird were higher than those of the largest Senkaku-type male bird. There were significant differences between Senkakuand Torishima-type male birds in 16 of 26 measurements, with Torishima-type birds being larger than Senkaku-type birds. There were no significant differences in EC and NF (Fig. S2).

PCA showed 2 principal components (PC) with eigenvalues larger than 1.0 (Table 2). PC1 and PC2 accounted for 51.9 and $20.6 \%$ of the total variance, respectively. Component loadings for PC1 were positive in all 9 measurements. As a higher PC1 score is related to a larger body size, PC1 score was regarded as an indicator of size. Meanwhile, component loadings for $\mathrm{PC} 2$ were positive for NF, Gape, TH, and EC. All measurements with positive component loadings were related to the beak length. Contrastingly, component loadings were negative for TAR, NFH, WS, TAIL, and NFW, none of which were related to beak length but were associated with other body elements or the robustness of beak. Therefore, higher 


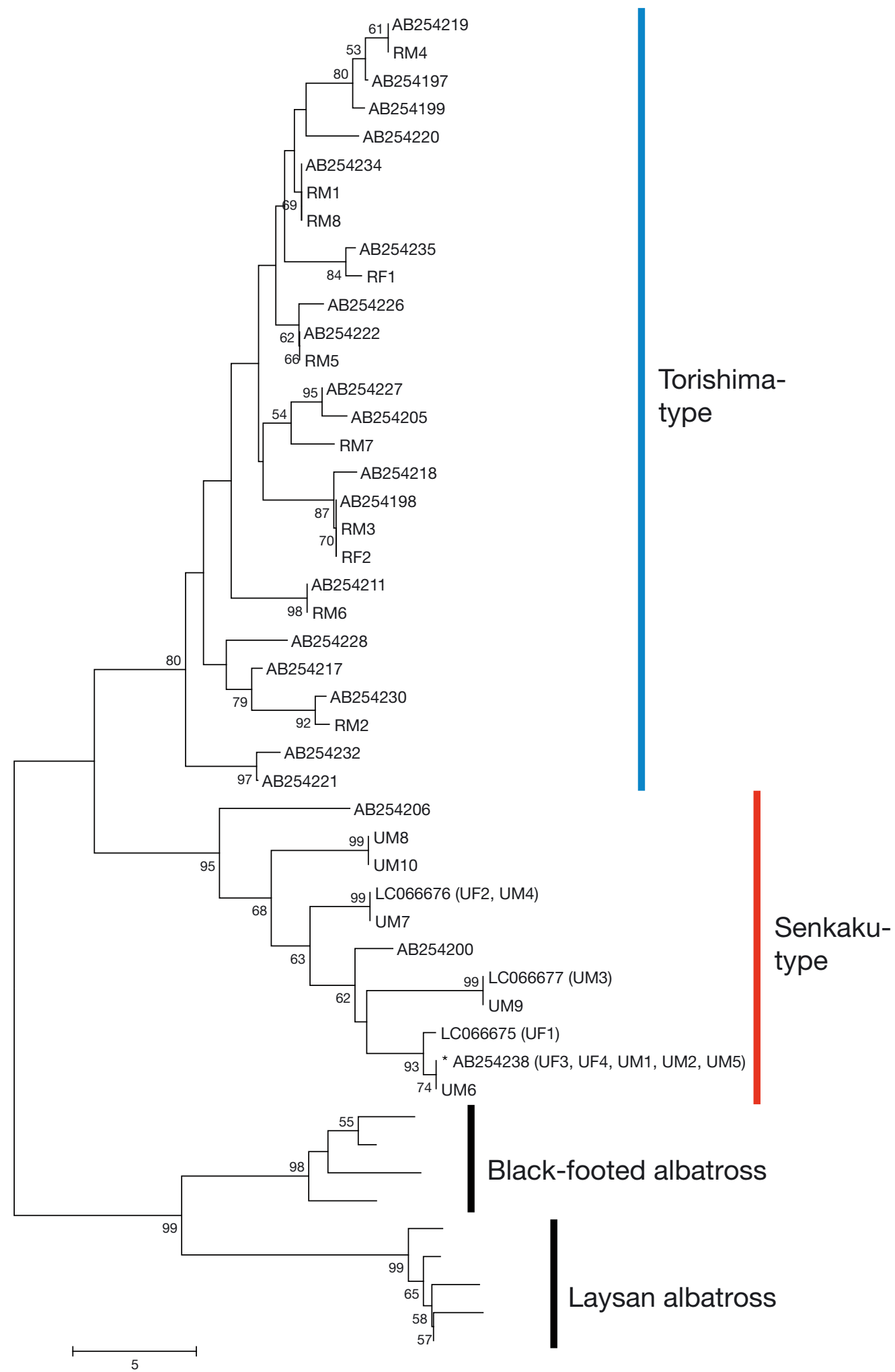

Fig. 2. Neighbour-joining tree for short-tailed albatross. Laysan and black-footed albatrosses were used as the outgroup. Bootstrap values over $50 \%$ obtained from 1000 resamplings are shown. R and U denote samples from ringed and unringed birds, respectively; $\mathrm{F}$ and $\mathrm{M}$ denote samples from female and male birds, respectively. ABxxxxx: sequences from birds at Tsubamezaki colony on Torishima; ${ }^{*}$ AB254238: sequence from birds in Senkaku Islands; LCxxxxx: sequences from unringed birds at Hatsunezaki colony on Torishima 
Table 2. Principal component scores for the 2 principal component axes based on 9 measurements of 24 short-tailed albatrosses

\begin{tabular}{|lcc|}
\hline \multirow{2}{*}{ Mensural points } & \multicolumn{2}{c|}{ Component loadings } \\
& PC1 & PC2 \\
\hline Half wing span (WS) & 0.635 & -0.416 \\
Tail length (TAIL) & 0.494 & -0.406 \\
Tarsus length (TAR) & 0.610 & -0.606 \\
Total head length (TH) & 0.732 & 0.435 \\
Beak to gape length (Gape) & 0.749 & 0.479 \\
Exposed culmen (EC) & 0.853 & 0.420 \\
Beak tip to nostrils front length (NF) & 0.766 & 0.512 \\
Beak height at nostrils front (NFH) & 0.804 & -0.429 \\
Beak width at nostrils front (NFW) & 0.773 & -0.323 \\
Eigenvalues & 4.67 & 1.85 \\
\% of total variance explained & 51.94 & 20.56 \\
\hline
\end{tabular}

PC2 score indicated relatively longer but thinner beaks. The PC scores scatterplot revealed that most males (with 2 exceptions in the Senkaku-type) had positive PC1 scores, whereas females had negative ones, and most Senkaku-type birds (with 2 exceptions) had positive PC2 scores, whereas Torishimatype birds had negative ones (Fig. 3).

Males from the 2 populations differed significantly in 3 beak measurements (BH, EC, and NFH) (Pillai's Trace $=0.774, F=11.160, \mathrm{df}=4,13, \mathrm{p}<0.001)$. There was no significant difference between the covariance matrices for males from the 2 populations $\left(\chi^{2}=10.79\right.$, $\mathrm{df}=10, \mathrm{p}>0.05)$, and the following linear discriminant functions for Senkaku- $\left(\mathrm{F}_{\mathrm{LSM}}\right)$ and Torishimatype males $\left(\mathrm{F}_{\text {LTM }}\right)$ were derived:

$\mathrm{F}_{\mathrm{LSM}}=-28270.777+13793.542 \times \mathrm{BH}+21067.330 \times$ $\mathrm{EC}-7527.422 \times \mathrm{NFH}$

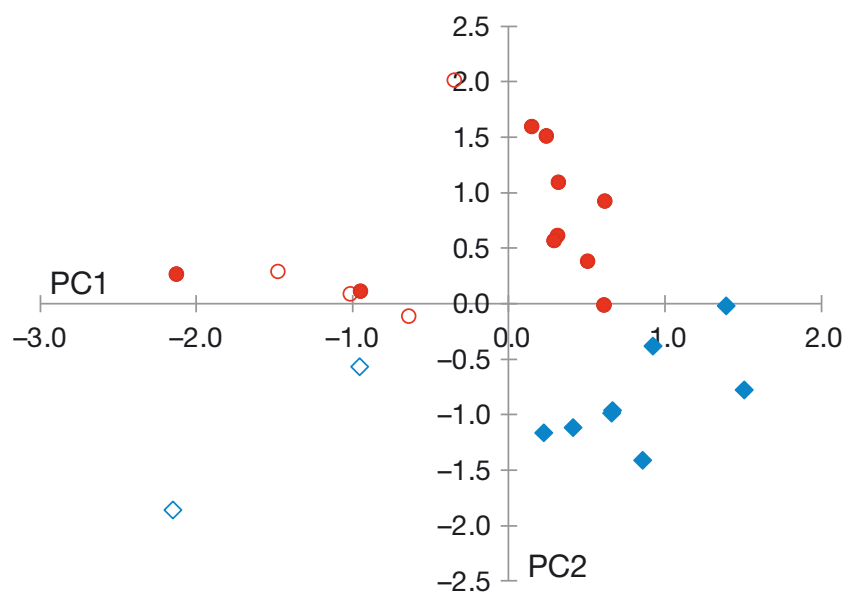

Fig. 3. Principal component analysis on 9 measurements of 24 short-tailed albatrosses. Red circles: Senkaku-type birds; blue rectangles: Torishima-type birds. Filled and empty symbols: males and females, respectively
$\mathrm{F}_{\text {LTM }}=-28420.975+14051.214 \times \mathrm{BH}+20889.911 \times$ $\mathrm{EC}-7474.601 \times \mathrm{NFH}$

In the leave-one-out classification, $89 \%$ of birds were correctly identified, and Senkaku- and Torishima-type birds were correctly identified with $90 \%$ (9 out of 10 individuals) and $88 \%$ ( 7 out of 8 individuals) accuracy, respectively.

Quadratic discriminant functions for Senkaku( $\left.\mathrm{F}_{\mathrm{QSM}}\right)$ and Torishima-type male $\left(\mathrm{F}_{\mathrm{QTM}}\right)$ were as follows:

$\mathrm{F}_{\mathrm{QSM}}=-18142.694+10840.443 \times \mathrm{BH}+11835.836 \times$ $\mathrm{EC}-4675.487 \times \mathrm{NFH}-7246.289 \times \mathrm{BH}^{2}-5398.385 \times$ $\mathrm{EC}^{2}-1264.094 \times \mathrm{NFH}^{2}+4609.896 \times \mathrm{BH} \times \mathrm{EC}+$ $2441.798 \times \mathrm{BH} \times \mathrm{NFH}+2151.18 \times \mathrm{EC} \times \mathrm{NFH}$

$\mathrm{F}_{\mathrm{QTM}}=-115853.159+53105.462 \times \mathrm{BH}+93836.103 \times$ $\mathrm{EC}-37254.71 \times \mathrm{NFH}-10994.199 \times \mathrm{BH}^{2}-21011.092$ $\times \mathrm{EC}^{2}-9316.3 \times \mathrm{NFH}^{2}-19757.91 \times \mathrm{BH} \times \mathrm{EC}+$ $16532.542 \times \mathrm{BH} \times \mathrm{NFH}+18436.724 \times \mathrm{EC} \times \mathrm{NFH}$

In the leave-one out classification using quadratic discriminant functions, all males were accurately classified into Senkaku- or Torishima-type. Practically, the following function is useful for the discrimination between bird types:

$\mathrm{F}_{\mathrm{QSM}}-\mathrm{F}_{\mathrm{QTM}}=97710.47-42265.02 \times \mathrm{BH}-82000.27 \times$ $\mathrm{EC}+32579.22 \times \mathrm{NFH}+3747.91 \times \mathrm{BH}^{2}+15612.71 \times$ $\mathrm{EC}^{2}+8052.21 \times \mathrm{NFH}^{2}+24367.806 \times \mathrm{BH} \times \mathrm{EC}-$ $14090.744 \times \mathrm{BH} \times \mathrm{NFH}-16285.544 \times \mathrm{EC} \times \mathrm{NFH}$

By substituting each $\log _{10}$-transformed measurement, the bird is determined as Senkaku- or Torishima-type when the sign is positive or negative, respectively.

\section{DISCUSSION}

\subsection{Morphological differences in the short-tailed albatross}

We captured 24 adult short-tailed albatrosses at the Hatsunezaki colony located on Torishima. Molecular sexing revealed that captured birds were biased to male (18 males and 6 females). Not only the raw measurement data but also the PCA, especially PC1, revealed that male birds were larger than female birds in both Senkaku- and Torishima-types. However, $t$-tests revealed significant morphological intersexual differences in only TL, TAR, and body weight in the Senkaku-type birds, as $t$-tests could not be conducted for the Torishima-type birds owing to the small number of measured female birds. Morphological sexual dimorphism, in which males were larger 
than females, has also been reported in other albatross species (Tickell 2000).

Average values for 24 of the 26 measurements were larger for Torishima-type males than those for Senkaku-type males, and 16 of them were significantly different according to $t$-tests. These results suggest that Torishima-type males are larger than Senkaku-type males in general. In measurements of short-tailed albatross carpometacarpi at an archaeological site from $\sim 1000 \mathrm{yr}$ ago, birds from the Torishima-type ancestral population were larger than those from the Senkaku-type ancestral population (Eda et al. 2012), suggesting that the body size difference between types has persisted for at least $1000 \mathrm{yr}$.

In contrast, average EC and NF were longer in Senkaku-type males than those in Torishima-type males, suggesting that morphological differences are not proportional. PCA, especially PC2 scores, supported this pattern and revealed that it also applied to female birds, i.e. not only male but also female Senkaku-type birds had higher PC2 scores, which indicated relatively longer and thinner beaks than those of both male and female Torishima-type birds. As beak shape is highly related to feeding behaviour and preference, the difference in beak between Senkaku- and Torishima-type birds is likely associated with adaptation to different food and/or environments. Despite the trend of assortative mating between 2 types of birds, ringed and unringed pairs likely raised hybrid chicks on Torishima and Bonin Islands (Eda et al. 2016, Deguchi et al. 2017), and hybridisation was confirmed by genetic analysis on Bonin Islands (Deguchi et al. 2017). In addition, pairs of Senkaku-type birds yielded chicks on Torishima (Eda et al. 2016). Morphological investigations on birds with parents of both the Torishima- and Senkakutype, and on Senkaku-type birds fledged from Torishima require further study.

Because all Torishima-type males had longer TL and heavier body weight than those of all Senkakutype males, these 2 measurements are useful for distinguishing between the 2 male types. However, the small sample size should be considered before drawing any significant conclusions, i.e. 8 and 10 males for Torishima- and Senkaku-type birds, respectively. Additional samples could show overlap in these measurements between both types. In addition, TL is difficult to measure for skin, especially for older individuals. Furthermore, body weight shows seasonal change and cannot be measured after a bird has been stuffed. Therefore, we conducted DFA to reveal the identification criteria between the Senkaku- and Torishima-type male birds. Results of leave-one-out classification revealed that all individuals were correctly identified by quadratic discriminant functions of 3 beak measurements, i.e. EC, BH, and NFH, suggesting that the morphometric approach is useful for discrimination between the 2 types of male birds. Because PCA showed a similar pattern of beak shape difference between female birds from the 2 types, it will be possible to establish the morphometric discrimination criteria for female birds if we conduct additional female bird measurements.

\subsection{Cryptic species in the short-tailed albatross}

The morphological differences found in this study support the idea of the presence of cryptic species. In genetic analysis, mtDNA CR2 sequences of modern short-tailed albatross from Torishima and the Senkaku Islands revealed that there were 2 distinct haplotypic clades, and that one was specific to Torishima and the other was distributed across both regions (Eda et al. 2010, 2011, Kuro-o et al. 2010). This genetic structure, the co-existence of 2 distinct lineages in a region, i.e. Phylogeographic Pattern II (Avise et al. 1987, Avise 2000), can be explained by 2 population history scenarios: (1) 2 isolated populations with recent admixture on Torishima, or (2) a population with a large evolutionarily effective population size and significant gene flow, in which 2 separate ancient lineages were retained by chance. Contrastingly, ancient DNA, stable isotope, and morphometric analyses of zooarchaeological bones from the Hamanaka 2 site revealed that birds from different clades formed different populations at that time $(\sim 1000 \mathrm{yr}$ ago $)$, and supports the first scenario, i.e. recent co-existence on Torishima (Eda 2004, Eda et al. 2012).

According to phylogenetic analysis, the sequence divergence in the cytochrome $b$ region of mtDNA between the 2 bird types (0.0061-0.0088) is greater than that between other Diomedeidae sister species, including those between the Campbell Thalassarche impavida and black-browed T. melanophris albatrosses (0.0026-0.0079) and between wandering Diomedea exulans and Amsterdam D. amsterdamensis albatrosses (0.0053) (Eda \& Higuchi 2012). Campbell and black-browed albatrosses are clearly different in their iris colour, whereas wandering and Amsterdam albatrosses are obviously different in their final plumage (Tickell 2000). These facts suggest that the divergence between Senkaku- and Torishima-type birds was large enough to accumulate genetic differences affecting phenotypic characteris- 
tics. Assuming the evolutionary rate of the third codon of cytochrome $b$ region sequence as $1.58 \%$ $\mathrm{Myr}^{-1}$ (Nunn et al. 1996), the genetic divergence between the 2 lineages occurred 638000 yr ago (Eda 2018).

From an ecological perspective, birds originating from Torishima and the Senkaku Islands were observed sympatrically on Torishima but paired assortatively with few exceptions, suggesting that Senkaku- and Torishima-type birds achieved a strong but incomplete pre-mating isolation (Eda et al. 2016). Incompatibility of mating displays and differences in the timing of breeding could be proximate cues that result in the trend of assortative mating in both bird types (Eda et al. 2016). Some differences in courtship displays between the 2 bird types were observed (F. Sato unpubl. data). In addition, the breeding season on the Senkaku Islands progresses earlier than that on Torishima, as birds on the Senkaku Islands departed from the breeding island $\sim 2$ wk earlier than those on Torishima in 2002 (Hasegawa 2006). In articles published over 100 yr ago, a similar trend was also reported for the short-tailed albatross on Kuba-jima and Uotsuri-jima islands in the Senkaku Islands (Kuroiwa 1900, Miyajima 1900), supporting the hypothesis that Senkaku-type birds have an earlier breeding season than Torishima-type birds. Difference in breeding phenology is recognised as one of the speciation mechanisms for seabird species without apparent physical barriers to dispersal (Friesen 2015). Furthermore, a lifespan difference in food intake between Senkaku- and Torishima-type birds was suggested by carbon and nitrogen stable isotope analyses of zooarchaeological bones (Eda et al. 2012).

Under the general lineage species concept, which defines a species as a 'separately evolving metapopulation lineage', evidence of morphological diagnosability, reciprocal monophyly, ecological difference, and intrinsic reproductive isolation support the inference of a species boundary (De Queiroz 2007). As mentioned above, Senkaku- and Torishima-type birds had diagnosable morphological characteristics, reciprocally monophyletic mtDNA sequences, a clear trend of assortative mating, and heterochronic breeding phenology. Despite the absence of physical barriers to dispersal, the 2 bird types evolved separately over the course of $\sim 638000 \mathrm{yr}$. Therefore, we propose that Senkaku- and Torishima-type birds should be classified as different cryptic species.

The short-tailed albatross Phoebastria albatrus was named by Pallas in 1769, based on specimens captured in the Kamchatka Sea, recently called the Sea of Okhotsk (Pallas 1769). It is difficult to determine whether Senkaku- or Torishima-type birds should inherit the species name $P$. albatrus, for 3 reasons. Firstly, the type locality, Sea of Okhotsk, has likely been used by both types of birds (Eda et al. 2012, N. Tomita et al. unpubl. data). Archaeological albatross remains ( 1000 yr ago) from the Hamanaka site on Rebun Island, located where the Sea of Japan and the Sea of Okhotsk meet, included bones from both types of birds (Eda 2004, Eda et al. 2012), and lightbased geolocator tracking revealed that both types of birds visit the Sea of Okhotsk (N. Tomita et al. unpubl. data). Secondly, the original description by Pallas (1769) is not sufficient for species identification. Although Pallas (1769) reported 1 value for each of 12 morphometric measurements, it is unclear whether they are comparable with the measurements in the present study and whether all of them were taken from the same individual. Finally, the type specimens were lost (V. Loskot and S. Frahnert pers. comm.). In addition to albatrus, at least 3 names for these species have been coined, i.e. chinensis, brachyura, and derogata. Nomenclatural studies are required to determine which type of bird takes the name albatrus and to determine an appropriate name for the other type.

\subsection{Implications for short-tailed albatross conservation}

After the extinction declaration in 1949 (Austin 1949), only 23 birds were observed on Torishima during the 1954-1955 breeding season (Fujisawa 1967), and the bird numbers and area of occupancy drastically declined within 3 generations (72.3 yr for the species) (Hasegawa \& DeGange 1982, BirdLife International 2018). Therefore, the combined taxon, shorttailed albatross $P$. albatrus sensu lato, was Critically Endangered under the current Red List guideline (IUCN Standards and Petitions Committee 2019) in the 1954-1955 breeding season. With great conservation efforts and considering it as a single management unit with 2 breeding sites, the species population increased thereafter and was listed as Vulnerable in the 2018 IUCN Red List under criteria D2 (BirdLife International 2018). However, the present study revealed that the species included cryptic species. To the best of our knowledge, this is the first case of cryptic species being identified in a threatened avian species.

When we consider that the species includes cryptic species, Senkaku- and Torishima-type albatrosses should be assessed and managed separately. Differ- 
ent cryptic species might require different conservation strategies (Schönrogge et al. 2002), as they may be exposed to different risks. Potential threats to the Senkaku-type birds are probably posed by their small population size and management problems for researchers owing to low accessibility due to political issues. At the end of the 2013-2014 breeding season, the number of mature birds was estimated to be 1734 (Deguchi et al. 2017, BirdLife International 2018). Assuming a similar demographic composition on the islands, the number of mature birds was estimated to be 1462 and 269 birds on Torishima and the Senkaku Islands, respectively. Thus, the estimated number of birds on Senkaku can be close to the limit at which a population is classified as 'Endangered' $(<250$; IUCN Standards and Petitions Committee 2019). A recent increasing trend of immigrants from the Senkaku Islands may be related to the environmental degradation of breeding island(s), or full carrying capacity preventing juveniles from recruiting to the Senkaku Islands. In addition, long-distance (>1500 km) dispersal of juvenile birds and a linear relationship between colony size and proportion of juveniles recruiting to their hatching place were observed in wandering albatross (Inchausti \& Weimerskirch 2002). Thus, colony size difference between the Senkaku Islands and Torishima could explain the dispersal trend from the Senkaku Islands. Research is urgently required at the Senkaku Islands to confirm the number of individuals and explain the increasing dispersal trend.

Torishima is an active volcanic island, and its eruption is a potential threat for Torishima-type birds. However, models have shown that even small increases in chronic mortality rates, such as those resulting from bycatch, would have a greater impact on population trends than stochastic and theoretically catastrophic events, including volcanic eruptions (Finkelstein et al. 2010). Comparative research on oceanic distribution between the Senkaku- and Torishima-type birds would be essential for estimating the risk of bycatch for each bird type.

The increasing trend in immigrants from the Senkaku Islands could affect the genetic integrity of Torishima-type birds through interspecific hybridisation. Viable $F_{1}$ hybrids have been reported in interspecies pairs in Diomedeidae, including species pairs of black-footed $\times$ Laysan albatrosses (Rohwer et al. 2014), Campbell $\times$ black-browed albatrosses (Moore et al. 2001), and northern royal Diomedea sanfordi $\times$ southern royal $D$. epomophora albatrosses (Robertson 1993). As the genetic distance between the Senkaku- and Torishima-type birds is much smaller than that between black-footed and Laysan alba- trosses (Eda \& Higuchi 2012, Eda et al. 2012), the divergence between the 2 types is unlikely to achieve complete post-mating isolation. In the Bonin Islands, 2 types of birds confirmed by genetic analysis paired and yielded chicks (Deguchi et al. 2017), suggesting that post-mating isolation mechanisms were not so strong between these types. Therefore, the robustness of pre-mating isolation is thought to have a major impact on whether the admixture of 2 types of birds will proceed. So far, 2 types of birds, discriminated by ring status, have shown a clear trend in assortative mating on Torishima, but $6.8 \%$ of the observed pairs were disassortative (Eda et al. 2016). It would be important to note that 2 sequences from the birds hatched at Tsubamezaki colony on Torishima (i.e. ringed birds) clustered with Senkakutype birds. Thus, some of the ringed birds may be descendants of Senkaku-type birds that emigrated from the Senkaku Islands and bred on Torishima. Future studies analysing the nuclear and mtDNA of ringed birds mating with unringed birds and their chicks are required to accurately evaluate the assortative and disassortative mating rates and to predict whether species boundaries between these 2 species break down over time.

The third breeding station, the Bonin Islands, could suffer more serious issues in this context. The colony was artificially established by the translocation and hand-rearing of 69 chicks from the Tsubamezaki colony of Torishima to Mukojima during 2008 and 2012, as a joint international conservation project between Japan and the USA (US Fish and Wildlife Service 2008, Deguchi et al. 2017). Although the possibility of including cryptic species was suggested in earlier work (Eda 2004), the project progressed without genetic assessment of translocated birds owing to the urgent requirements for establishing a third stable breeding location and the lack of taxonomic information about birds on the Senkaku Islands. The translocated birds would be mainly Torishima-type birds but could include Senkaku-type birds, which represented $\sim 7 \%$ of hatched birds in the Tsubamezaki colony (Kuro-o et al. 2010). As the hand-reared birds may not have the ability to recognise the different cryptic species and/or their original bird types, they would thus not be able to mate assortatively. Under genetically uninformed management efforts, as a further example, the widespread and Critically Endangered Chinese giant salamander, which consists of at least 5 species-level lineages, was genetically homogenised in captivity, and hybrid offspring were released back into the wild (Yan et al. 2018). To exclude the risk of artificial population admixture, a 
paring census and genetic monitoring of chicks fledged from the Bonin Islands using mtDNA and microsatellite DNA are required. The present study also emphasises the need for genetic assessments of seemingly well-known threatened avian species in conservation initiatives.

Acknowledgements. Special thanks to Hiroyoshi Higuchi (Keio University), who provided valuable comments on the study. The information on the lost type specimens of the short-tailed albatross was provided by Vladimir Loskot (Zoological Institute, Russian Academy of Sciences) and Sylke Frahnert (Natural History Museum, Berlin). Insightful comments from 2 anonymous reviewers clarified the strengths and weaknesses of this study. This study was partially financially supported by the Ministry of the Environment Government of Japan, Tokyo Metropolitan Government, US Fish and Wildlife Service, the Mitsui \& Co. Environment Fund, the Suntory Fund for Bird Conservation, Keidanren Nature Conservation Fund, and JSPS KAKENHI Grant Number JP15K14439.

\section{LITERATURE CITED}

Abbott CL, Double MC, Trueman JWH, Robinson A, Cockburn A (2005) An unusual source of apparent mitochondrial heteroplasmy: duplicate mitochondrial control regions in Thalassarche albatrosses. Mol Ecol 14:3605-3613

Adams M, Raadik TA, Burridge CP, Georges A (2014) Global biodiversity assessment and hyper-cryptic species complexes: More than one species of elephant in the room? Syst Biol 63:518-533

Austin O (1949) The status of Steller's albatross. Pac Sci 3: 283-295

Avise JC (2000) Phylogeography: the history and formation of species. Harvard University Press, Cambridge, MA

Avise JC, Arnold J, Ball RM, Bermingham E and others (1987) Intraspecific phylogeography: the mitochondrial DNA bridge between population genetics and systematics. Annu Rev Ecol Syst 18:489-522

Baba Y, Siegfried K, Yue-Hua S, Fujimaki Y (2005) Molecular phylogeny and population history of the Chinese grouse and the hazel grouse. Bull Grad Sch Soc Cult Stud Kyushu Univ 11:77-82

Bickford D, Lohman D, Sodhi N, Ng P, Meier R, Winker K, Ingram K (2007) Cryptic species as a window on diversity and conservation. Trends Ecol Evol 22:148-155

*BirdLife International (2017) Phoebastria albatrus (amended version of 2016 assessment). The IUCN Red List of Threatened Species 2017:eT22698335A110678513. doi:10. 2305/IUCN.UK.2017-1.RLTS.T22698335A110678513.en (accessed 12 May 2020)

* BirdLife International (2018) Phoebastria albatrus. The IUCN Red List of Threatened Species 2018:e.T22698335A1326 42113. doi:10.2305/IUCN.UK.2018-2.RLTS.T22698335A 132642113.en (accessed 12 May 2020)

Bowen BW, Meylan AB, Avise JC (1991) Evolutionary distinctiveness of the endangered Kemp's ridley sea turtle. Nature 352:709-711

Davidson-Watts I, Walls S, Jones G (2006) Differential habitat selection by Pipistrellus pipistrellus and Pipistrellus pyg- maeus identifies distinct conservation needs for cryptic species of echolocating bats. Biol Conserv 133:118-127

* De Queiroz K (2007) Species concepts and species delimitation. Syst Biol 56:879-886

* Deguchi T, Jacobs J, Harada T, Perriman L and others (2012) Translocation and hand-rearing techniques for establishing a colony of threatened albatross. Bird Conserv Int 22: $66-81$

* Deguchi T, Sato F, Eda M, Izumi H and others (2017) Translocation and hand-rearing result in short-tailed albatrosses returning to breed in the Ogasawara Islands 80 years after extirpation. Anim Conserv 20:341-349

Eda M (2004) Inferring short-tailed albatross population structure from modern and archaeological samples. $\mathrm{PhD}$ dissertation, The University of Tokyo

Eda M (2018) Izushoto Torishima no Field Chousa to Hokkaido Rebunto no Isekisiryou no Bunseki kara Senkaku Shoto no Ahoudori wo Saguru (Inferring the history of short-tailed albatross in Senkaku Islands from field survey on Torishima and zooarcheological samples from Rebun Island). In: Mizuta T, Tagkagi M (eds) Shima no Chourui Gaku (Ornithology on islands). Kaiyu Sha, Tokyo, p 77-94 (in Japanese)

Eda M, Higuchi H (2012) Does the short-tailed albatross Phoebastria albatrus consist of two species!? Jpn J Ornithol 61:263-272 (in Japanese with English Abstract)

Eda M, Kuro-o M, Higuchi H, Hasegawa H, Koike H (2010) Mosaic gene conversion after a tandem duplication of mtDNA sequence in Diomedeidae (albatrosses). Genes Genet Syst 85:129-139

Eda M, Sato F, Koike H, Higuchi H (2011) Genetic profile of Deko-chan, an un-ringed short-tailed albatross in Torishima Island, and the implication for the species' population structure. J Yamashina Inst Ornithol 43:57-64

*Eda M, Koike H, Kuro-o M, Mihara S, Hasegawa H, Higuchi $H$ (2012) Inferring the ancient population structure of the Vulnerable albatross Phoebastria albatrus, combining ancient DNA, stable isotope, and morphometric analyses of archaeological samples. Conserv Genet 13:143-151

Eda M, Izumi H, Konno S, Konno M, Sato F (2016) Assortative mating in two populations of short-tailed albatross Phoebastria albatrus on Torishima. Ibis 158:868-875

* Finkelstein ME, Wolf S, Goldman M, Doak DF, Sievert PR, Balogh G, Hasegawa H (2010) The anatomy of a (potential) disaster: volcanoes, behavior, and population viability of the short-tailed albatross (Phoebastria albatrus). Biol Conserv 143:321-331

FFridolfsson AK, Ellegren H (1999) A simple and universal method for molecular sexing of non-ratite birds. J Avian Biol 30:116-121

F Friesen VL (2015) Speciation in seabirds: Why are there so many species...and why aren't there more? J Ornithol 156:27-39

Fujisawa I (1967) Ahoudori (short-tailed albatross). TokoShoin, Tokyo (in Japanese)

Hasegawa H (2003) 50 wa kara 5000 wa he (From fifty to five thousand). Doubutsu-sha, Tokyo (in Japanese)

Hasegawa H (2006) Ahoudori ni Muchu (Addicted to the short-tailed albatross). Shin Nippon Shuppansya, Tokyo (in Japanese)

Hasegawa H (2015) Okino-tayu no Shima de (On the island of the short-tailed albatross). Kaisei Sha, Tokyo (in Japanese)

Hasegawa H, DeGange AR (1982) The short-tailed albatross, Diomedea albatrus, its status, distribution and nat- 
ural history. Am Birds 36:806-814

Inchausti P, Weimerskirch H (2002) Dispersal and metapopulation dynamics of an oceanic seabird, the wandering albatross, and its consequences for its response to longline fisheries. J Anim Ecol 71:765-770

IUCN Standards and Petitions Committee (2019) Guidelines for using the IUCN Red List categories and criteria. Version 14. http://cmsdocs.s3.amazonaws.com/RedListGuide lines.pdf (accessed on 12 May 2020)

Kumar S, Stecher G, Tamura K (2016) MEGA7: molecular evolutionary genetics analysis version 7.0 for bigger datasets. Mol Biol Evol 33:1870-1874

Kuro-o M, Yonekawa H, Saito S, Eda M, Higuchi H, Koike $\mathrm{H}$, Hasegawa H (2010) Unexpectedly high genetic diversity of mtDNA control region through severe bottleneck in Vulnerable albatross Phoebastria albatrus. Conserv Genet 11:127-137

Kuroiwa H (1900) Senkaku Retto Tanken Kiji (Expedition in the Senkaku Islands). J Geog 12:476-483, 528-543 (in Japanese)

Miyajima M (1900) Okinawa Kenka Mujinto Tankendan (Exploring uninhabited islands in Okinawa Prefecture). J Geog 12:585-596 (in Japanese)

Moore PJ, Burg TM, Taylor GA, Millar CD (2001) Provenance and sex ratio of black-browed albatross, Thalassarche melanophrys, breeding on Campbell Island, New Zealand. Emu 101:329-334

Nunn GB, Cooper J, Jouventin P, Robertson CJR, Robertson GG (1996) Evolutionary relationships among extant albatrosses (Procellariiformes: Diomedeidae) established from complete cytochrome- $b$ gene sequences. Auk 113:784-801

Ono Y (1955) Status of birds on Torishima: particularly of the Steller's albatross. Jpn J Ornithol 14:24-32 (in Japanese with English Abstract)

Pallas PS (1769) Spicilegia zoologica quibus novae imprimis et obscurae animalium species iconibus, descriptionibus atque commentariis illustrantur, Vol 1. Gottlieb August Lange, Berolini

Pérez-Ponce de León G, Poulin R (2016) Taxonomic distribution of cryptic diversity among metazoans: not so homogeneous after all. Biol Lett 12:20160371

Pfenninger M, Schwenk K (2007) Cryptic animal species are homogeneously distributed among taxa and biogeographical regions. BMC Evol Biol 7:121

Ravaoarimanana IB, Tiedemann R, Montagnon D, Rumpler

Editorial responsibility: Mike Bruford,

Cardiff, UK
Y (2004) Molecular and cytogenetic evidence for cryptic speciation within a rare endemic Malagasy lemur, the northern sportive lemur (Lepilemur septentrionalis). Mol Phylogenet Evol 31:440-448

Research Group for Senkaku Islands at Ryukyu University (1971) Senkaku Retto Gakujyutsu Chousa Houkoku (Research Report for Senkaku Islands). Ryukyu University, Naha (in Japanese)

Robertson CJR (1993) Timing of egg laying in the royal albatross (Diomedea epomophora) at Taiaroa Head 19371992. Conservation Advisory Science Notes No. 50. Department of Conservation, Wellington

Rohwer S, Harris RB, Walsh HE (2014) Rape and the prevalence of hybrids in broadly sympatric species: a case study using albatrosses. PeerJ 2:e409

Sato F (1999) Hiren no Deko-chan (A grief of Deko-chan). Yamashina Institute for Ornithology News. Yamashina Institute for Ornithology, Abiko, p 4-5 (in Japanese)

Sato F (2009) Increase in pairs of the short-tailed albatross Diomedea albatrus at an artificial breeding ground. J Yamashina Inst Ornithol 40:139-143

K Schönrogge K, Barr B, Wardlaw JC, Napper E and others (2002) When rare species become endangered: cryptic speciation in myrmecophilous hoverflies. Biol J Linn Soc 75:291-300

Sugawara H, Watabe T, Yoshikawa T, Nagano M (2018) Morphological and molecular analyses of Hynobius dunni reveal a new species from Shikoku, Japan. Herpetologica 74:159-168

Tickell WLN (2000) Albatrosses. Yale University Press, New Haven, CT

US Fish and Wildlife Service (2008) Short-tailed albatross recovery plan. US Fish and Wildlife Service, Anchorage, AK

Winker K (2005) Sibling species were first recognized by William Derham (1718). Auk 122:706-707

Yamashina Institute for Ornithology (2005) Deko-chan Futatabi Ninkimono ni (Repopularized Deko-chan). Yamashina Institute for Ornithology News (in Japanese)

Yamashina Institute for Ornithology (2002-2015) Report on the bird banding scheme for 2001-2013. Yamashina Institute for Ornithology, Abiko

Yan F, Lü J, Zhang B, Yuan Z and others (2018) The Chinese giant salamander exemplifies the hidden extinction of cryptic species. Curr Biol 28:R590-R592

Submitted: May 13, 2020; Accepted: September 17, 2020

Proofs received from author(s): November 16, 2020 